Anuario da Facultade de Dereito da Universidade da Coruña

Vol. 23 (2019), pp. 261-286

ISSNe: 2530-6324 || ISSN: 1138-039X

DOI: https://doi.org/10.17979/afdudc.2019.23.0.6019

\title{
EXTINCIONES INDIVIDUALES DEL CONTRATO DE TRABAJO EN EMPRESAS EN CONCURSO, PRECONCURSO Y CONCURSO SOBREVENIDO $^{1}$
}

\author{
INDIVIDUAL EXPIRATION OF THE EMPLOYMENT \\ CONTRACT IN COMPANIES IN STATE OF INSOLVENCY (OR \\ THE PRE-STATE OF INSOLVENCY), OR WHEN THE STATE OF \\ INSOLVENCY HAPPENS SUDDENLY
}

\author{
ISABEL OLMOS PARÉS \\ Magistrada especialista de la Sala de lo Social \\ Tribunal Superior de Justicia de Galicia
}

\begin{abstract}
Resumen: La compatibilidad entre la extinción individual del contrato de trabajo, al amparo de la acción que el art. $501^{\circ} \mathrm{b}$ ) del Estatuto de los Trabajadores (ET) concede a los trabajadores y el concurso de acreedores (o el preconcurso), o cuando sobreviene el concurso, es una cuestión compleja, dada la solución arbitrada por la ley concursal de convertirla en una extinción de tipo colectivo, con la consiguiente pérdida de competencia del juez social en favor del juez mercantil. Las diversas soluciones e interpretaciones a los problemas que sobre esta cuestión se vienen planteando en los tribunales es el objeto fundamental de este trabajo.
\end{abstract}

Palabras clave: concurso, extinción, contrato de trabajo, acción individual, trabajador.

Abstract: The compatibility between the individual expiration of the employment contract, under the shelter of the action that art. $\left.501^{\circ} \mathrm{b}\right)$ of the Estatuto de los Trabajadores (workers regulations) concedes to workers, and the state of insolvency (or the pre-state of insolvency), or when the state of insolvency happens suddenly, is a complex matter, on account of the solution mediated by the Act on Insolvency to transform it in a collective expiration, with the consequent loss of competency of the social judge in favour of the commercial judge. The divergent solutions and interpretations to the issues which have been contemplated in the courts about this matter, is the fundamental objective of this work.

\footnotetext{
${ }^{1}$ Este artículo será objeto de publicación por parte del Consejo General del Poder Judicial, dentro de la colección Cuadernos Digitales de Formación de 2019, en el monográfico Aspectos socio-laborales del concurso, habiendo obtenido autorización de fecha 24 de junio de 2019 para la presente publicación en el Anuario de la UDC.
} 
Keywords: state of insolvency, expiration, employment contract, individual action, worker.

Sumario: I. INTRODUCCIÓN. II. PROBLEMAS DE COMPETENCIA JUDICIAL. 1. Demanda extintiva individual posterior a la solicitud del concurso. 2. Demanda extintiva individual anterior a la solicitud de concurso. A. Competencia del juez mercantil. B. Competencia del juez de lo social. 3. Extinciones individuales por despido tácito. 4. Extinciones individuales y grupo de empresas. A. Concepto de grupo. B. Grupo de empresas dentro del concurso. III. EXTINCIONES INDIVIDUALES EN SITUACION DE PRECONCURSO. IV. EXTINCIONES INDIVIDUALES EN EL CASO DE ACUERDO EXTRAJUDICIAL DE PAGOS. V. EXTINCIONES INDIVIDUALES EN SITUACIÓN DE CONCURSO SOBREVENIDO. VI. BIBLIOGRAFÍA.

\section{INTRODUCCIÓN}

Una empresa declarada en concurso puede proceder a la extinción de los contratos de trabajo de sus trabajadores operando todas las causas de extinción previstas en el art. 49 del Estatuto de los Trabajadores (en adelante ET) ${ }^{2}$. Pero, a diferencia de cuando se halla en una situación extraconcursal, en caso de concurso, si la extinción es colectiva, en otras palabras, un despido colectivo, precisará de autorización del juez del concurso (juez mercantil). De este modo, la competencia del juez mercantil lo es solo respecto de los despidos colectivos, causa de extinción del contrato de trabajo prevista en la letra i) del art. 49 del ET. Así es que todo lo que no sea un despido colectivo, el régimen jurídico será el previsto en el ET y su enjuiciamiento seguirá siendo competencia del juez social. Es por ello que si el despido colectivo ya se ha consumado antes de la declaración del concurso, ninguna competencia tendrá el juez del concurso, las cuales se limitan a autorizar o denegar los despidos colectivos que se produzcan después de la declaración del concurso, de conformidad con lo dispuesto en el art. 64.7 de la Ley Concursal (en adelante LC) ${ }^{3}$, sin que quepa declarar la nulidad del procedimiento de despido colectivo ${ }^{4}$, al no estarse en ninguna de las circunstancias relacionadas en el art. 124.11 de la Ley Reguladora de la Jurisdicción social (en adelante LRJS) ${ }^{5}$.

Pero como siempre hay una excepción a la regla general (solo es competencia del juez mercantil los despidos colectivos), el art. $6410^{\circ}$ de la LC prevé un mecanismo para hacer valer la concursalidad de determinadas acciones individuales del art. 50 del ET (art. $6410^{\circ}$ de la LC), es decir, en convertir en colectivas las extinciones que en principio son individuales.

En ese sentido, la Ley Concursal de 2003 introdujo en el art. 64 un apartado

\footnotetext{
${ }^{2}$ Real Decreto Legislativo 2/2015, de 23 de octubre, por el que se aprueba el texto refundido de la Ley del Estatuto de los Trabajadores (ET).

${ }^{3}$ Ley 22/2003, de 9 de julio, Concursal (LC).

${ }^{4}$ Véase la Sentencia del Tribunal Superior de Justicia, Sala de lo Social, de 5 de diciembre de 2013 (ROJ: STSJ AND 14490/2013).

${ }^{5}$ Ley 36/2011, de 10 de octubre, reguladora de la jurisdicción social (LRJS).
} 
$10^{\circ}$ en el que se extendió la competencia del juez del concurso, por conversión en una extinción de carácter colectivo, para conocer de una determinada suma de acciones individuales que, al amparo del art. $501^{\circ} \mathrm{b}$ ) del ET (impago o retraso en el pago de los salarios), habían ejercido un grupo de trabajadores, fijando a su vez los umbrales a partir de los cuales se producía la conversión ${ }^{6}$.

El art. $6410^{\circ}$ de la LC, tal y como estaba redactado antes de la reforma del año $2011^{7}$, generó graves disfunciones que no vale la pena recordar, pero sí conviene resaltar que el principal problema práctico se producía en el caso de que se estuviera tramitando en el concurso un expediente de extinción colectiva a instancia del deudor o de la administración concursal en el que se hallaran incluidos nominalmente trabajadores que a su vez habían accionado en un procedimiento social de extinción ex art. $501^{\circ} \mathrm{b}$ ) del ET, esto es, cuando se simultaneaba un expediente del art. 64 de la LC y al mismo tiempo un procedimiento laboral de extinción del contrato accionando por vía del art. 50 $1^{\circ}$ b) ET en el que coincidían en todo o en parte los trabajadores afectados. Las soluciones fueron muchas y variadas: bien que cada orden jurisdiccional siguiera conociendo, pues cada jurisdicción conservaba su competencia siendo como eran diferentes las acciones en liza y las consecuencias jurídicas de cada una, de modo que quién primero extinguía el contrato de trabajo era quién determinaba las condiciones de la extinción (45 días o 20 días); bien que una de las jurisdicciones, por defecto la social, suspendiese actuaciones a la espera de lo que decidiese el juez del concurso o bien, que el juez del concurso otorgara una indemnización de 45 días (hoy serían 33 días) por años de servicios en lugar de los 20 días previstos en el art. $518^{\circ}$ del ET en el caso de que los trabajadores cuyo contrato de trabajo era extinguido por el juez del concurso hubieran planteado previamente una acción extintiva ex art. $501^{\circ}$ b) del E.T. Incluso se dio el caso de que el juez mercantil extinguió al amparo del art. 64 de la LC y después la jurisdicción social acordó una mayor indemnización, en concreto la diferencia entre la otorgada por el juez mercantil y la prevista en la legislación laboral para el incumplimiento empresarial previsto en el art. $501^{\circ}$ b) de ET (45 días de salario por año de servicio por entonces) $)^{8}$.

La solución que la Reforma de la LC adopta en la Ley 38/2011, trata de evitar la disparidad de soluciones y por ende, las disfunciones que ello llevó aparejadas ${ }^{9}$. De

\footnotetext{
${ }^{6}$ El art. $6410^{\circ}$ de la LC establecía en su redacción original que: "Las acciones individuales interpuestas al amparo de lo previsto en el artículo 50.1.b) del Estatuto de los Trabajadores tendrán la consideración de extinciones de carácter colectivo a los efectos de su tramitación ante el juez del concurso por el procedimiento previsto en el presente artículo, cuando la extinción afecte a un número de trabajadores que supere, desde la declaración del concurso, los límites siguientes: ...”.

${ }^{7}$ Ley 38/2011, de 10 de octubre de reforma de la Ley 22/2003, de 9 de julio, Concursal.

${ }^{8}$ Véase la Sentencia del Tribunal Superior de Justicia de Galicia, Sala de lo Social, de 28 de marzo de 2008 (ROJ: STSJ GAL 23/2008), o la de la misma Sala, de 18 de julio de 2008 (ROJ: STSJ GAL 8748/2008).

${ }^{9}$ En la actualidad, el art. $6410^{\circ}$ de la LC tras la reforma establece que "Las acciones resolutorias individuales interpuestas al amparo del artículo 50 del Estatuto de los Trabajadores motivadas por la situación económica o de insolvencia del concursado tendrán la consideración de extinciones de carácter colectivo, desde que se acuerde la iniciación del expediente previsto en este artículo, para la extinción de los contratos. Acordada la iniciación del procedimiento previsto en este artículo, la totalidad de los procesos individuales seguidos frente a la concursada posteriores a la solicitud de concurso pendientes de resolución firme se suspenderán hasta que adquiera firmeza el auto que ponga fin al expediente de extinción colectiva. La resolución que acuerde la suspensión se comunicará a la administración concursal, a los efectos del reconocimiento como contingente del crédito que pueda resultar de la sentencia que en su día se dicte, una vez alzada la suspensión. Igualmente se comunicará a los tribunales ante los que estuvieren tramitan-
} 
este modo, vaya ya por delante, con carácter general puede afirmase que el juez mercantil es competente para extinguir el contrato de trabajo de cualquier trabajador de la empresa concursada, siempre y cuando su contrato no haya sido extinguido previamente por el juez social con ocasión de una demanda presentada al amparo del art. 50 del ET, ya que el contrato no puede ser extinguido dos veces.

Procede destacar también que, con la reforma de 2011, el mecanismo de concursalidad ya no se ciñe al apartado b) del art. $501^{\circ}$ b) del ET sino a todo el art. $50 \mathrm{ET}$, esto es, cualquier incumplimiento grave y culpable imputado al empresario pero, eso sí, motivado por la situación económica o la insolvencia, ampliando así la competencia del juez de concurso antes limitada sólo al apartado b) del art. $501^{\circ}$ del ET. Por lo tanto, se incluyen tanto las demandas resolutorias por falta de pago del salario, como por retraso en el pago del salario, como por falta de ocupación efectiva generada por esa por esa situación de crisis empresarial, lo que supone incluir los casos de despidos tácitos. Quedan excluidas las demandas de extinción por causa independiente de la situación económica como son las relativas a extinción por vulneración de derechos fundamentales (por ejemplo, el acoso moral) o las modificaciones sustanciales en las condiciones de trabajo llevadas a cabo sin respetar el art. 41 del ET que redunden en perjuicio de su dignidad, pero que no traigan causa a su vez, en la situación económica de la empresa (y que lógicamente no sean colectivas).

\section{PROBLEMAS DE COMPETENCIA JUDICIAL}

\section{Demanda extintiva individual posterior a la solicitud del concurso}

Este supuesto está resuelto en la propia norma. No hay duda de que la conversión en colectivas afecta a la totalidad de las acciones (demandas) individuales posteriores a la solicitud de concurso "pendientes de resolución firme", una vez se inicia el ERE concursal. Es evidente que la norma trata de evitar la simultaneidad de dos vías extintivas, la que se hace más evidente en situación concursal, y no tanto por la exigencia del principio de la unidad del procedimiento concursal, sino por la especial trascendencia que tendría para la situación patrimonial del concursado que los contratos de trabajo se extinguiesen con la máxima indemnización prevista en el ordenamiento laboral, lo que justifica su tratamiento dentro del concurso.

Del tenor literal de la norma parece extraerse que las reclamaciones individuales afectadas son las que estuvieran en trámite en el momento de iniciarse el expediente colectivo de extinción, siempre que se hubieran presentado después de la solicitud del concurso $^{10}$. Las resueltas antes, lógicamente no quedarían afectadas por el concurso ${ }^{11}$, pues la jurisprudencia entiende que no cabe extinguir por segunda vez una relación laboral declarada previamente inexistente ${ }^{12}$, pero ¿qué ocurre con las no resueltas si fuese anteriores a la solicitud del concurso? Después volveré sobre ello.

\footnotetext{
do los procedimientos individuales. El auto que acuerde la extinción colectiva producirá efecto de cosa juzgada sobre los procesos individuales suspendidos”.

10 RODRIGUEZ ACHUTEGUI, Edmundo: Reforma del sistema de relaciones laborales y concurso. Madrid: CGPJ, 2012 (Cuadernos Digitales de Formación 41).

${ }^{11}$ Véase la Sentencia del Tribunal Superior de Justicia de Andalucía, sección 1, del 4 de julio de 2018 (ROJ: STSJ AND 8810/2018).

12 Véanse la Sentencia del Tribunal Supremo, Sala de lo Social, de 22 junio 2011 (ROJ: STS 5066/2011) y la Sentencia del Tribunal Supremo, Sala de lo Social, de 11 de julio de 2011 (ROJ: STS 6225/2011).
} 
En otro orden de cosas, la norma debería haber dicho definitiva, pues la expresión "resolución firme" permite que la suspensión se produzca incluso cuando exista sentencia de instancia recurrida en suplicación (hay sentencia definitiva, la de instancia, pero no es firme) en cuyo caso lo que queda suspendida es la tramitación del recurso de suplicación, de modo que incluso en ese caso, se producirá la suspensión, y por tanto la posibilidad de incluir al trabajador que tiene una sentencia del juzgado de lo social extinguiendo su contrato, pero pendiente de recurso de suplicación.

En todo caso, si la demanda extintiva individual es posterior en el tiempo a la solicitud del concurso no existe duda de que cualquiera que sea el trámite en que se encuentre, mientras no exista resolución firme de extinción del juez social, deberá suspenderse para que el juez mercantil pueda extinguir el contrato, si es el caso, y ello desde el momento en que se inicie el ERE concursal.

El momento a partir del cual se debe considerar que la extinción deviene colectiva y pasa a manos del juez del concurso es desde que se inicie el procedimiento del art. 64 LC, lo que ofrece dudas de si hace referencia a la mera solicitud o a la admisión por el juez de la solicitud de inicio, lo que parece resolverse a continuación cuando señala: “Acordada la iniciación...”. De este modo, la misma providencia de admisión de la solicitud del expediente del art. 64 LC permitirá la aplicación del citado precepto. Ello supone que solo en situación de concurso será posible la citada conversión colectiva, pues solo en situación concursal es posible plantear el procedimiento de extinción colectiva de contratos de trabajo al amparo del art. 64 de la LC, nunca en situación de preconcurso. En ese caso habrá que acudir al procedimiento de despido colectivo, aplicándose el régimen previsto en el ET, lo que será analizado más adelante.

Solamente cabe añadir, a efectos de la aplicación del artículo $6410^{\circ}$ de la LC que es irrelevante con arreglo al texto de la LC, en orden a la competencia y procedimiento para resolver sobre la pretensión resolutoria esgrimida en la demanda individual, que con anterioridad a la presentación de ésta hubiera recaído auto declarando a la empresa en situación de concurso voluntario. Desde la entrada en vigor de la Ley 38/2011, de 10 de octubre, la fecha que ha de tomarse en consideración, por sus efectos sobre estos procesos, es aquélla en la que se inicie el expediente de extinción colectiva de contratos de trabajo en aplicación del artículo 64 de la LC, no la fecha del auto de declaración del concurso. La mera situación concursal de la empresa no afecta, por ello, a la tramitación y eventual estimación de la demanda resolutoria con arreglo a los criterios propios de la legislación laboral, que son los arriba expuestos ${ }^{13}$.

\section{Demanda extintiva individual anterior a la solicitud de concurso}

\section{A. Competencia del juez mercantil}

La jurisprudencia, bajo la vigencia de la norma anterior, es decir, aplicando el art. $6410^{\circ}$ de la LC en su redacción anterior a la reforma producida por la ley 38/2011, consideró que la competencia del juez mercantil le permitía extinguir el contrato de trabajo de un trabajador que había accionado vía art. $501^{\circ}$ b) del ET, y por ello incluirlo en

\footnotetext{
13 Véase la Sentencia del Tribunal Superior de Justicia de Castilla-León, Sala de lo Social, de 14 de octubre de 2015 (ROJ: STSJ CL 4540/2015).
} 
el ERE y luego en el auto extintivo, aunque su demanda fuese previa a la solicitud de concurso, o previa al auto de declaración de concurso, siempre y cuando la misma no hubiese finalizado a medio de sentencia firme ${ }^{14}$. Esa doctrina entiende que el Juez de lo Mercantil es competente para resolver la extinción colectiva de los contratos de trabajo, incluido el del trabajador que tiene pendiente demanda ante el Juzgado de lo Social sobre extinción del contrato al amparo del art. $501^{\circ}$ b) del ET (también por analogía una acción de despido tácito), aunque sea una demanda anterior a la declaración del concurso $^{15}$, y ello, porque de la dicción literal del art. 64 de la LC no se desprende que el Juez Mercantil pierda la competencia para decidir acerca de la extinción colectiva de contratos cuando consta presentada demanda resolutoria del art. 50 del ET ante la jurisdicción social. Y ello sobre la base - sobre todo- de que la existencia de esta última demanda no supone la existencia de litispendencia respecto a la acción de extinción colectiva de contratos, y en segundo lugar, porque la mera presentación de demanda resolutoria no tiene incidencia sobre la vigencia del contrato ${ }^{16}$.

Sin embargo, la redacción actual de la norma plantea dudas, dada la expresión legal de que los efectos de consideración como colectivas se producen "desde que se acuerde la iniciación del expediente previsto en este artículo", y en relación a "la totali-

\footnotetext{
${ }^{14}$ Véase la Sentencia del Tribunal Supremo, Sala de lo Social, de 13 de abril de 2011 (ROJ: STS 3846/2011), dónde se trataba de "determinar si la de extinción contractual declarada en el seno concurso, al amparo de los arts. 50.1 b) ET y 64.10 LC, debe seguir el régimen indemnizatorio del art. 51.8 ET , en el que a los despidos colectivos se señala una indemnización de 20 días por año trabajado con un máximo de 12 mensualidades, o, si por el contrario, se puede mantener el que fija el art. 50 ET, de 45 días por año trabajado con el máximo de 42 mensualidades, y, por ende, la responsabilidad del FGS de 30 días por año del art. 33.2 párrafo segundo ET”. En ella se concluye que: "La disyuntiva ha de ser resuelta en el sentido de que la colectivización de la medida extintiva significa necesariamente la aplicación íntegra del régimen de los despidos colectivos, lo que alcanza también el monto de la indemnización. Tras el Auto de declaración de concurso, la situación de concurso de la empresa no sólo provoca la competencia del Juez del concurso para el control y autorización de la extinción, sino que tiene efectos sustantivos en la misma y, al remitirlo al del art. 51.8 ET, transforma el régimen jurídico aplicable a esta modalidad de extinción contractual”.

${ }^{15}$ Véase la Sentencia del Tribunal Supremo, Sala de lo Social, de 9 de febrero de 2015 (ROJ: STS 717/2015), también bajo la vigencia del art. $6410^{\circ}$ de la LC, antes de su reforma por ley 38/2011, en un supuesto en que los trabajadores habían interpuesto demanda de extinción de contrato ante el Juzgado de lo Social antes de que se declarara el concurso (en fecha 31 de enero de 2011), y por auto de 16 de febrero de 2011 se declaró en concurso voluntario a la entidad demandada, presentando la concursada el día 24 de dicho mes de febrero escrito solicitando la extinción colectiva de una parte de los contratos de los trabajadores de la empresa, en concreto de 71 trabajadores, habiendo dictado auto el 9 de mayo de 2011 en que se autorizaba la extinción de parte de los trabajadores incluidos en el auto de extinción, en concreto 29, que habían presentado escrito alegando la falta de competencia exclusiva y excluyente del Juzgado de lo Mercantil para resolver sobre la extinción de los contratos de dichos trabajadores, por haber presentado éstos el 31 de enero de 2011 demanda de extinción de contratos ante los Juzgados de lo Social de Barcelona, al amparo del artículo 50 del Estatuto de los Trabajadores, no habiendo recaído aún sentencia, y de 13-4-2016 (Recurso 2874/2014).

${ }^{16}$ Por ello, la Sentencia del Tribunal Supremo, Sala de lo Social, de 9 de febrero de 2015 (ROJ: STS 717/2015), afirma expresamente que "no se plantea si el Juez de lo Social es competente para conocer la demanda de extinción del contrato de trabajo, formulada por los trabajadores ante dicho Juzgado, al amparo del artículo 50.1 b) ET, con anterioridad a que la empresa fuera declarada en concurso. La cuestión litigiosa es si es posible que el Juez de lo Mercantil resuelva la extinción colectiva de contratos de trabajadores de una empresa que se encuentra en concurso cuando, previamente, algunos de dichos trabajadores han formulado demanda de extinción del contrato de trabajo, ante el Juzgado de lo Social, al amparo del artículo 50.1 b) ET y dicha demanda no ha sido aún resuelta", afirmándose a continuación que "el Juez de lo Social es competente para conocer de la demanda interpuesta por el trabajador, al amparo del artículo 50.1 b) ET, solicitando la extinción de su contrato, ya que la misma fue presentada con anterioridad a que la empresa fuera declarada en concurso".
} 
dad de los procesos individuales seguidos frente a la concursada posteriores a la solicitud del concurso pendiente de resolución firme”, que estén fundadas en la misma causa de insolvencia que ha llevado al concurso. Así, podría considerarse que tal efecto de considerar las extinciones como colectivas solo se produciría respecto de las demandas interpuestas a partir de un determinado momento; y en cambio las demandas interpuestas por la misma razón con anterioridad a tal momento seguirían siendo individuales, sin consideración a que ambas están fundadas en la misma causa. El momento sería el de la solicitud de concurso.

Conforme al art. 3.1 Código Civil, "Las normas se interpretarán según el sentido propio de sus palabras, en relación con el contexto, los antecedentes históricos y legislativos, y la realidad social del tiempo en que han de ser aplicadas, atendiendo fundamentalmente al espíritu y finalidad de aquellas”. Atendiendo a estos criterios parte de la doctrina judicial ha considerado que es la concurrencia de la causa económica y no el momento de la interposición de las demandas lo que funda el tratamiento como colectiva de la extinción de los contratos, y partiendo de que sobre tales temas de extinción colectiva de contratos los Juzgados de lo Mercantil tienen competencia exclusiva y excluyente, de existir concurso de acreedores (art. 8.1 LC); el juez del concurso puede extinguir cualquiera que sea el momento en que se presente la demanda o demandas individuales ${ }^{17}$.

Esta doctrina judicial, partiendo de la Jurisprudencia del TS ya citada y anterior a la reforma de la LC por la ley 38/2011, desglosa el art. $6410^{\circ}$ en dos partes. Conforme la primera parte del texto legal, "las acciones resolutorias individuales interpuestas al amparo del artículo 50 del Estatuto de los Trabajadores, motivadas por la situación económica o de insolvencia del concursado, tendrán la consideración de extinciones de carácter colectivo, desde que se acuerde la iniciación del procedimiento previsto en este artículo, para la extinción de los contratos”. Su interpretación es la de que las acciones resolutorias individuales tendrán la consideración de extinciones de carácter colectivo, todas, desde que se acuerde la iniciación del procedimiento previsto en este artículo, momento en el que pasarán a ser colectivas desde individuales que eran, y por tanto solo podrán resolverse en el incidente concursal. De este modo el primer párrafo del art. $6410^{\circ}$ de la LC dispone la consideración como extinciones colectivas de todas las demandas de extinción de contrato fundadas en el art. 50 ET, siempre que en realidad se basen en la causa económica que ha llevado al concurso de acreedores a la empresa. El único límite sería si hubiese sentencia firme del orden social que hubiera extinguido ya el contrato. No es pues el momento de interposición de la demanda o la papeleta de conciliación lo que determina la calificación como extinciones individuales sometidas al art. 50 ET, o como colectivas sometidas al art. 64 LC, pues este momento, y este es un argumento principal, puede adelantarse, por interés de obtener una indemnización mayor, aun cuando sea obvia para todos en la empresa la situación de insolvencia, o ésta se prevea claramente.

La consideración como colectivas tendrá lugar pues, según esta doctrina judicial, desde que se acuerde la iniciación del procedimiento, y ello ocurrirá respecto de

\footnotetext{
${ }^{17}$ Véase la Sentencia del Tribunal Superior de Justicia de Cataluña, Sala de lo social, de 18 de mayo de 2016 (ROJ: STSJ CAT 4288/2016), dónde la demanda extintiva individual era de fecha 3 de marzo de 2015 y el auto de declaración de concurso de 8 de mayo de 2015 (la solicitud de concurso voluntario de 23-4-14); la solicitud de extinción colectiva de 20 de mayo de 2015, y el auto extintivo de fecha 29 de junio de 2015.
} 
"las acciones resolutorias individuales interpuestas al amparo del artículo 50 del Estatuto de los Trabajadores, motivadas por la situación económica o de insolvencia del concursado". Son pues todas las acciones individuales las que se consideran como colectivas a partir del inicio del incidente concursal, y en modo alguno únicamente las acciones interpuestas a partir del inicio de tal incidente (tampoco las acciones interpuestas después de la solicitud del concurso). Ello lleva a la conclusión necesaria de que todas las acciones individuales son consideradas colectivas, y tal consideración tiene lugar lógicamente a partir del momento en que la extinción colectiva se solicita con el inicio del incidente concursal ${ }^{18}$.

¿Cómo interpreta esta misma doctrina judicial el segundo inciso del primer párrafo del art. $6410^{\circ}$ de la LC?

Conforme a él, “acordada la iniciación del procedimiento previsto en este artículo, la totalidad de los procesos individuales seguidos frente a la concursada posteriores a la solicitud del concurso pendiente de resolución firme, se suspenderán hasta que adquiera firmeza el auto que ponga fin al procedimiento de extinción colectiva”. Para esta doctrina judicial, esta norma, de naturaleza procesal, que no sustantiva, carece de todo sentido entenderla en el sentido de "procesos iniciados con posterioridad a la solicitud del concurso", a fin de limitar a estas demandas posteriores a la fecha de solicitud del concurso los efectos que establece a continuación la norma, de que los procesos laborales individuales se suspenderán y en ellos se producirá el efecto de cosa juzgada, para a la vez excluir de tales efectos los procesos iniciados con anterioridad a la fecha de tal solicitud, aunque fuera un día o unos días antes, y aunque concurra la misma causa para la extinción, de modo que estos procesos continúen tramitándose después de la declaración del concurso. Se concluye que "proceso seguido con posterioridad a la solicitud del concurso”, significa un proceso que se tramita o sigue tramitándose después de este momento. Se dice que dentro de esa expresión legal se incluyen no solo los procesos iniciados después de la solicitud de concurso y que siguen tramitándose lógicamente después de la solicitud del concurso, sino también los procesos iniciados antes de la solicitud de concurso y que siguen con posterioridad, siempre que no hayan finalizado por resolución firme. De este modo, cuando se solicita el concurso, todos los procedimientos pendientes ante el orden social (seguidos) son susceptibles de ser reconvertidos en extinciones colectivas a los efectos de que el juez del concurso pueda extinguirlos, a través del expediente concursal del art. 64 de la LC.

En el mismo sentido, aunque con otros matices, se ha dicho que el art. $6410^{\circ}$ LC en su primer párrafo "regula específicamente la situación de las demandas de resolución del contrato de trabajo mientras que el segundo inciso de dicha norma, que distingue entre demandas previas al concurso y demandas posteriores al mismo, se refiere al resto de demandas que puedan dirigirse frente a la concursada lo cual cohonesta la excepción del párrafo inicial de este apartado con el art. 50.1 LC no aplicable por lo tanto en la situación debatida”19.

\footnotetext{
${ }^{18}$ Véase en el mismo sentido la Sentencia del Tribunal Superior de Justicia de Cataluña, Sala de lo Social, de 10 de mayo de 2016 (ROJ: STSJ CAT 4070/2016); y la Sentencia del Tribunal Superior de Justicia de Cataluña, Sala de lo social, de 29 de abril de 2016 (ROJ: STSJ CAT 3934/2016).

${ }^{19}$ Véase la Sentencia del Tribunal Superior de Galicia, Sala de lo social, de 28 de junio de 2016 (ROJ: STSJ GAL 5289/2016). Entre sus argumentos se halla, también, el que la demanda del actor es anterior al preconcurso que presentó la empresa, lo que podría ser equiparado a la solicitud de concurso; luego reconoce que las demandas previas al concurso de las que habla el precepto son las mismas a las que se refiere
} 
Lo que se defiende, en definitiva, es que no puede aceptarse que aquellas demandas presentadas antes de la solicitud de concurso puedan seguir libremente y ser tratadas de forma distinta (sin suspensión ni vinculados por la cosa juzgada), si a la fecha del inicio del ERE concursal aún están pendientes de extinción por el juez de lo social, sometiéndolos al mismo tratamiento de los que han sido presentados después, pues todos ellos son procesos seguidos frente a la concursada con posterioridad a la solicitud del concurso (o posteriores a la solicitud del concurso), lo que por otro lado es obvio, pues nunca el procedimiento de extinción colectiva se iniciará antes de la solicitud del concurso.

Esta doctrina se apoya también, ya se ha dicho, en el hecho de que el momento de interposición de la demanda puede adelantarse, por interés de obtener una indemnización mayor, aun cuando sea obvia para todos en la empresa la situación de insolvencia, o ésta se prevea claramente. Especialmente puede ocurrir en supuestos en que los trabajadores recurrentes reconocen en su escrito que "en el momento de la presentación de la demanda la empresa estaba en situación de preconcurso al amparo del art. 5 bis, pero sin haber presentado solicitud de concurso voluntario en sede mercantil”. Más adelante trataré sobre el preconcurso.

Esta doctrina, además, ha propiciado que muchos juzgados y tribunales de lo social se hayan declarado incompetentes incluso si la demanda es anterior a la solicitud de concurso, si el contrato ya ha sido extinguido por el juez mercantil ${ }^{20}$, cuando realmente estamos ante una pérdida sobrevenida del objeto litigioso.

\section{B. Competencia del juez de lo social}

La doctrina judicial contraria, partiendo de la premisa de que corresponden a la jurisdicción social las acciones individuales (demandas) interpuestas al amparo del art. 50 del ET, aún motivadas por la situación económica o de insolvencia del concursado, no pueden tener la consideración de extinciones de carácter colectivo, es decir, no se produce la conversión si son anteriores en el tiempo a la fecha de la solicitud del concurso $^{21}$.

Expuesta de otro modo, también se ha dicho que, si se interponen estas acciones extintivas incluso tras el auto de declaración del concurso, pero antes del inicio del expediente concursal de extinción colectiva de contratos, estas acciones corresponden a la jurisdicción social, conforme al art. $6410^{\circ}$ de la LC. Es obvio, dado que mientras no haya ERE concursal, no puede haber conversión. Pero a continuación se añade que, con-

el primer inciso, esto es, las demandas individuales de extinción del contrato, al amparo del artículo 50 del Estatuto de los Trabajadores, motivadas por la situación económica o de insolvencia del concursado, lo que podría ser equiparado a la solicitud de concurso; luego reconoce que las demandas previas al concurso de las que habla el precepto son las mismas a las que se refiere el primer inciso, esto es, las demandas individuales de extinción del contrato, al amparo del artículo 50 del Estatuto de los Trabajadores, motivadas por la situación económica o de insolvencia del concursado.

${ }^{20}$ Véase la Sentencia del Tribunal Superior de Justicia de Castilla la Mancha, Sala de lo Social, de 19 de febrero de 2018 (ROJ: STSJ CLM 226/2018), que confirma la incompetencia del orden social declarada en la instancia por sentencia de 30 de mayo de 2017, en el caso de acción ejercitada antes de la declaración de concurso, dónde el juez mercantil, además, extinguió todos los contratos por auto de 29-11-2016.

${ }^{21}$ Véase la Sentencia del Tribunal Superior de Justicia del País Vasco, Sala de lo Social, de 23 de mayo de 2017 (ROJ: STSJ PV 1798/2017). 
forme al mismo art. $6410^{\circ}$ de la LC, acordada la iniciación del ERE concursal, solo los procesos individuales seguidos frente a la concursada posteriores a la solicitud del concurso pendientes de resolución firme han de suspenderse hasta que adquiera firmeza el auto que ponga fin al expediente de extinción colectiva ${ }^{22}$.

Esta doctrina llegó a admitir incluso que el Juez de lo Social en sentencia de fecha posterior a la de dictado por el Juez de lo Mercantil del Auto de extinción colectiva, puede extinguir el contrato de una trabajadora otorgando la indemnización correspondiente al despido improcedente $-\mathrm{y}$ no la del despido objetivo fijada por el juez del concurso-, haciendo coincidir la fecha de extinción con la acordada por el Auto del Juez de lo Mercantil ${ }^{23}$, con base a que, en los últimos años, el Tribunal Supremo ha flexibilizado el criterio de pervivencia del vínculo, en el sentido de que el hecho de que el trabajador, por decisión propia, haya dejado de prestar servicios simultáneamente, o con posterioridad, al ejercicio de la acción resolutoria y antes de que se celebre el acto de juicio, asumiendo el riesgo del resultado del proceso, no excluye la resolución del contrato en los términos del artículo 50 anteriormente mencionado ${ }^{24}$.

Lo que subyace además en toda esta doctrina judicial es la afirmación tajante de que en cualquier caso nunca existe pérdida de la competencia por parte del juez social, pues, aunque se afirma que todos los procedimientos pendientes ante el juzgado de lo social pueden quedar afectados por la posible extinción colectiva del juez mercantil, con independencia del momento de su inicio, se añade que la solución no es la incompetencia del juez social, sino la suspensión del procedimiento, la que solo podrá producirse respecto de los posteriores a la solicitud del concurso, de modo que en relación a ellos el juez social ni podrá extinguir, pero tampoco podrá declararse incompetente; tan solo suspender, lo que implica que retiene la competencia ${ }^{25}$. Si llegado el caso, el contrato se ha extinguido ya por el juez mercantil, habrá pérdida sobrevenida del objeto ${ }^{26}$.

\footnotetext{
${ }^{22}$ Véase la Sentencia del Tribunal Superior de Justicia de Cataluña, Sala de lo Social, de 8 de junio de 2018 (ROJ: STSJ CAT 4727/2018), en relación a una demanda de extinción contractual por impagos de salarios, unida a la reclamación de cantidad, y que entiende que la misma compete a la jurisdicción social, por ser una demanda de extinción individual interpuesta tras la declaración del concurso, pero antes del inicio del ERE concursal. Por tanto, procede anular todo lo actuado conservando el decreto de admisión de la demanda, debiendo acordar el Juzgado la suspensión de los autos hasta que se dicte auto en el expediente concursal- Incidente extinción relaciones laborales, y el mismo sea firme; momento en que el Juzgado de lo Social podrá alzar la suspensión acordada y resolver sobre las pretensiones formuladas partiendo de los pronunciamientos de dicho auto, que tendrá fuerza de cosa juzgada.

${ }^{23}$ Véase la STSJ, Sala de lo Social, de 23 de mayo de 2017 (ROJ: STSJ PV 1798/2017), pero esta doctrina ha sido rectificada por otra de la misma Sala, por ejemplo, la Sentencia del Tribunal Superior de Justicia del País Vasco, Sala de lo Social, de 16 de enero de 2018 (ROJ: STSJ PV 210/2018).

${ }^{24}$ Véase por todas la Sentencia del Tribunal Supremo, Sala de lo Social, de 15 de septiembre de 2016 (ROJ: STS 4196/2016).

${ }^{25}$ Véase la Sentencia del Tribunal Superior de Justicia de Cataluña, Sala de lo Social, de 8 de junio de 2018 (ROJ: STSJ CAT 4727/2018), en relación a una demanda de extinción contractual por impagos de salarios, unida a la reclamación de cantidad, y que entiende que la misma compete a la jurisdicción social, por ser una demanda de extinción individual interpuesta tras la declaración del concurso, pero antes del inicio del ERE concursal. Por tanto, procede anular todo lo actuado conservando el decreto de admisión de la demanda, debiendo acordar el Juzgado la suspensión de los autos hasta que se dicte auto en el expediente concursal- Incidente extinción relaciones laborales, y el mismo sea firme; momento en que el Juzgado de lo Social podrá alzar la suspensión acordada y resolver sobre las pretensiones formuladas partiendo de los pronunciamientos de dicho auto, que tendrá fuerza de cosa juzgada.

${ }^{26}$ Véase la Sentencia del Tribunal Supremo, Sala de lo Social, de 29 de junio de 2017 (ROJ: STS 2899/2017).
} 
Una cosa es que el juez mercantil sea competente para extinguir cualquier contrato de trabajo de la empresa concursada, y otra que el juez de lo social haya perdido la competencia para extinguir, si el juez mercantil todavía no lo ha hecho. Como mucho, el juez social deberá suspender la tramitación del procedimiento a la espera de lo que decida el juez mercantil, pero nunca declararse incompetente. Si la demanda es anterior a la solicitud de concurso, podrá continuar, pues la demanda no está afectada por la suspensión ${ }^{27}$.

Es cierto que la dicción literal del art. $6410^{\circ}$ de la LC establece una regla de conversión en colectivas de toda acción extintiva individual (o despido tácito por analogía), desde que se inicie el ERE concursal. De este modo, se ha defendido por la doctrina mencionada en el epígrafe anterior, que el juez mercantil es competente para extinguir el contrato de trabajo de cualquier trabajador de la empresa concursada, cuyo contrato no ha sido extinguido por sentencia firme. Ese es el sentido de la jurisprudencia del TS también arriba mencionada, anterior a la reforma de 2011. Cosa distinta es, sin embargo, que el juez social se declare incompetente, por el mero hecho de tener conocimiento del ERE, aunque éste no haya concluido por auto extintivo. Y es que la normael art. $6410^{\circ}$ de la LC- prevé soluciones diversas distinguiendo entre demandas anteriores y demandas posteriores a la solicitud de concurso (procesos individuales seguidos frente a la concursada posteriores a la solicitud del concurso pendiente de resolución firme), lo que presupone que hasta que el contrato no se haya extinguido el juez social mantiene la competencia, bien sea para suspender (en el caso de procesos-demandasposteriores a la solicitud de concurso), bien sea para seguir y extinguir en el caso de procesos-demandas-anteriores a la solicitud de concurso ${ }^{28}$.

Aunque, como hemos visto, la mayor parte de la doctrina judicial ha considerado que el art. $6410^{\circ} \mathrm{LC}$ permite que todas las acciones-demandas extintivas-puedan ser reconvertidas en colectivas cualquiera que sea el momento en que las mismas hayan sido presentadas, la misma se contradice en sí misma al asumir la posibilidad de recuperar la competencia del orden social, cuando a la postre el juez mercantil rechace la extinción colectiva, o bien decida no extinguir determinados contratos, entre ellos los de los trabajadores con demandas extintivas pendientes en la jurisdicción social ${ }^{29}$. O se es competente o no se es. Lo que no puede afirmarse es que se pierde la competencia por la mera existencia de un ERE concursal, todavía sin decisión extintiva. A mi juicio, el precepto, art. $6410^{\circ}$ de la LC tiene por único fin, todo él, el regular y coordinar las demandas individuales de extinción del contrato, al amparo del artículo 50 del ET, motivadas por la situación económica o de insolvencia del concursado, y que, a efectos de la com-

\footnotetext{
27 Véase la Sentencia del Tribunal Supremo, Sala de lo Social, de 20 de julio de 2016 (ROJ: STS 4026/2016) como declara que el juez social no puede suspender y archivar la demanda extintiva si es anterior a la solicitud de concurso. Véase también, cómo en la Sentencia del Tribunal Supremo, Sala de lo social, de 9 de febrero de 2015 (ROJ: STS 717/2015), se dice que: "En efecto, no se plantea si el Juez de lo Social es competente para conocer la demanda de extinción del contrato de trabajo, formulada por los trabajadores ante dicho Juzgado, al amparo del artículo 50.1 b) ET, con anterioridad a que la empresa fuera declarada en concurso. La cuestión litigiosa es si es posible que el Juez de lo Mercantil resuelva la extinción colectiva de contratos de trabajadores de una empresa que se encuentra en concurso cuando, previamente, algunos de dichos trabajadores han formulado demanda de extinción del contrato de trabajo, ante el Juzgado de lo Social, al amparo del artículo 50.1 b) ET y dicha demanda no ha sido aún resuelta”.

${ }^{28}$ Véase en ese sentido el voto particular emitido en la Sentencia del Tribunal Superior de Galicia, Sala de lo social, de 28 de junio de 2016 (ROJ: STSJ GAL 5289/2016).

${ }^{29}$ Véase la Sentencia del Tribunal Superior de Galicia, Sala de lo social, de 28 de junio de 2016 (ROJ: STSJ GAL 5289/2016).
} 
petencia, es preciso distinguir entre demandas previas a la solicitud del concurso y demandas posteriores al mismo.

El objeto de la competencia del juez social es la competencia para extinguir el contrato de trabajo vía el art. 50 del ET. De este modo solo la perderá en el momento en que el juez del concurso haya decidido la medida extintiva colectiva. Hasta ese momento el juez social la mantiene, si es una demanda anterior a la solicitud del concurso. La competencia no puede ser discutida sobre la base de que el juez mercantil pueda extinguir ad futurum, aunque no lo haya hecho en el momento de enjuiciamiento del juez social, manteniéndose viva por tanto la relación laboral. No hay norma que limite el derecho de los trabajadores a solicitar, ante los Juzgados de lo Social, la extinción de sus contratos, al amparo del artículo 50 ET, antes o durante la tramitación de un ERE, sin perjuicio de que el Juez Mercantil pueda también acordar la extinción de esos mismos contratos.

Tampoco está en vigor la redacción del art. $51.1^{\circ}$ de la LC que, antes de la reforma de la LC acometida por la ley 38/2011, permitía al juez mercantil acumular al concurso las juicios declarativos que siendo competencia del juez del concurso conforme al art. 8 (la extinción colectiva lo es), estimaba que su resolución tenía trascendencia sustancial para la formación del inventario o de la lista de acreedores ${ }^{30}$. El actual art. 51 $1^{\circ}$ de la LC señala ahora que: "Los juicios declarativos en que el deudor sea parte y que se encuentren en tramitación al momento de la declaración de concurso continuarán sustanciándose ante el mismo tribunal que estuviere conociendo de ellos hasta la firmeza de la sentencia. Por excepción se acumularán de oficio al concurso, siempre que se encuentren en primera instancia y no haya finalizado el acto de juicio o la vista, todos los juicios por reclamación de daños y perjuicios a la persona jurídica concursada contra sus administradores o liquidadores, de hecho o de derecho, y contra los auditores”.

Cómo se comprueba, nada indica sobre la posibilidad de que el juez del concurso pretenda esa acumulación (de las demandas extintivas) requiriendo de inhibición a los juzgados de lo social en estos casos como antes sucedía ${ }^{31}$.

Y la regla especial, el ya mencionado art. $6410^{\circ}$ de la LC, no arbitra un sistema de acumulación, sino de suspensión de las demandas individuales posteriores a la solicitud del concurso, desde el momento en que se inicie el ERE concursal, lo que viene a ser en la práctica una regla que resuelve una suerte de cuestión prejudicial conexa, muy cercana a la litispendencia, aunque no lo sea, lo que se corrobora después en el propio texto legal por la eficacia de cosa juzgada que el auto extintivo del juez del concurso tendrá sobre los procedimientos individuales, de modo que mientras no se produzca la

\footnotetext{
${ }^{30}$ Esta era además la redacción era la vigente en el momento de los hechos enjuiciados en la sentencia del Tribunal Supremo, Sala de lo Social, de 9 de febrero de 2015 (ROJ: STS 717/2015).

31 Téngase en cuenta que en los supuestos resueltos por la Sala de conflictos del TS sobre esta cuestión, la cuestión que se hallaba en la base del mismo era el requerimiento de inhibición que el juzgado de lo mercantil había hecho al juzgado de lo social. Y dicha posibilidad ya no está prevista en el art. $511^{\circ}$ de la LC. En todo caso, el cambio de criterio del que se hace eco, por ejemplo el Auto del Tribunal Supremo, Sala de Conflictos, de 3 de noviembre de 2015 (ROJ: ATS 8923/2015) en relación al criterio precedente de la Sala de conflictos y contenido, por ejemplo, en el Auto del Tribunal Supremo, Sala de Conflictos, de 28 de septiembre de 2011 (ROJ: ATS 10265/2011), se produce sobre la base de la Jurisprudencia del TS, esto es, con cita expresa de la Sentencia del Tribunal Supremo, Sala de lo social, de 9 de febrero de 2015 (ROJ: STS 717/2015).
} 
cosa juzgada, el juez social retiene la competencia, tanto si las demandas son o no anteriores a la solicitud del concurso.

Se trata del efecto positivo de la cosa juzgada, que exige la identidad subjetiva, de suerte que el pronunciamiento de la primera sentencia (aquí auto del juez del concurso) se presente como un "antecedente lógico de la otra”, lo que es cosa distinta de la litispendencia, y que ya aparece así distinguido por la doctrina jurisprudencial más reciente ${ }^{32}$.

En estos casos de mera conexión, la solución, evidentemente, no es la exclusión del segundo proceso, sino que pasaría por aplicar, en su caso, las reglas de la acumulación de los dos procesos. Así lo prevén nuestras normas procesales. De forma expresa, la LEC en su art. $761^{\circ}$ de la LEC, al establecer como supuestos en que procede la acumulación "cuando la sentencia que haya de recaer en uno de los procesos pueda producir efectos prejudiciales en el otro"; y lo mismo el art. $762^{\circ}$ del mismo texto legal, cuando "entre los objetos de los procesos cuya acumulación se pide existe tal conexión que, de seguirse los dos procesos por separado, parece claro que podrían dictarse sentencias con pronunciamientos o fundamentos contradictorios, incompatibles o mutuamente excluyentes".

Si la acumulación no es posible, o no está prevista como es el caso, existe una segunda solución cuál es la prevista de forma novedosa por la vigente LRJS, en su art. $864^{\circ}$ de la LRJS que dispone lo siguiente: "no obstante, a solicitud de ambas partes, podrá suspenderse el procedimiento hasta que recaiga resolución firme en otro procedimiento distinto, cuando en éste deba resolverse la que constituya objeto principal del primer proceso". Se trata de una fórmula muy parecida al art. 43 de la LEC, pero a diferencia de la fórmula del art. 43 de la LEC, en el procedimiento laboral se exige que sean ambas partes las que lo soliciten para que así se acuerde, mientras que en la LEC basta con que la pida una sola de las partes.

La conclusión es que la regla especial de suspensión del art. $6410^{\circ}$ de la LC resuelve un problema de conexión, por ello es temporal, lo que es muy distinto a afirmar la incompetencia del juez social, que es definitiva. Pero la suspensión o no del proceso social a la espera de lo que acontezca en el concurso es una decisión del juez social, luego es competente. A mi juicio, esta solución explica y justifica la retención de la competencia entre el juez social hasta que se produzca la cosa juzgada, de manera que pueda arbitrar una solución a la conexidad, pero nunca declarándose incompetente cuándo, cómo es el caso, no está resuelta la cuestión principal, la que provoca la conexión, esto es, la extinción del contrato.

En definitiva, considero que si el Juzgado de lo Social tiene conocimiento de la tramitación de un ERE, que afecte a la empresa concursada, y éste no ha sido resuelto en el momento de resolver las correspondientes demandas de extinción, ex artículo 50 ET, deberá suspender, o en su caso seguir (si la demanda es anterior a la solicitud del concurso), y sólo si los contratos ya se han extinguido por el Juez Mercantil, en el seno del procedimiento concursal, no podrá volver a extinguirlos, pues como concluye la Sala Cuarta, si cuando el Juzgado de lo Mercantil dicta el Auto extintivo no ha alcanza-

32 Véase, al efecto, la Sentencia del Tribunal Supremo, Sala de lo Social, de 23 enero 2006 (ROJ: STS 547/2006), y la Sentencia del Tribunal Supremo, Sala de lo Social, de 22 de abril de 2010 (ROJ: STS 2105/2010). 
do firmeza el pronunciamiento del orden social, es el Juzgado de lo Mercantil el que extingue la relación laboral, quedando el proceso del orden social sin objeto - porque la relación laboral ya se ha extinguido ${ }^{33}$ -

En otro orden de cosas, también existen razones materiales de fondo. Téngase en cuenta que la acción extintiva puede prosperar si la situación de impago alcanza por ejemplo tres mensualidades y una paga extra, o dos mensualidades y dos pagas extras ${ }^{34}$, es decir, que antes de la solicitud de concurso se ha podido consolidar una situación de impago grave (más de tres meses), teniendo en cuenta, además, que los pagos ulteriores empresariales no pueden dejar sin efecto el dato objetivo de la existencia de un incumplimiento empresarial grave, es decir no enerva la acción, aunque la deuda de cantidad se vea reducida ${ }^{35}$.

En relación a la acción extintiva por impago o retrasos en el pago del salario la doctrina jurisprudencial se puede resumir en los siguientes puntos: 1) no es exigible para la concurrencia de la causa de resolución del artículo 50.1.b) ET la culpabilidad en el incumplimiento del empresario; 2) para que prospere la causa resolutoria se exige exclusivamente el requisito de gravedad en el incumplimiento empresarial; y 3) este criterio objetivo de valoración del retraso continuado, reiterado o persistente en el pago de la retribución no es de apreciar cuando el retraso no supera los tres meses ${ }^{36}$.

La doctrina jurisprudencial como vemos hace coincidir el tiempo a partir del cual puede considerarse el incumplimiento grave (más de tres meses) con el presupuesto objetivo del concurso, esto es, con el momento en el que el deudor debe solicitar la declaración de concurso, que lo es dentro de los dos meses siguientes a la fecha en que hubiera conocido o debido conocer su estado de insolvencia, y se equipara a insolvencia el impago de las tres últimas mensualidades. Si el empresario ha dejado de pagar tres meses de salario, y previsiblemente no podrá hacer frente a la siguiente mensualidad no solo está obligado a pedir la declaración de concurso, sino que se enfrentará a una posible demanda extintiva, en la que la situación de insolvencia en la que se encuentre no es un elemento que permita atenuar o valorar su culpabilidad, pues como se ha dicho, no es exigible la culpa del empresario.

Sin embargo, la solicitud de concurso puede demorarse en el tiempo, no solo por la existencia, por ejemplo, de un preconcurso, sino por el simple hecho de que el empresario deudor tiene un plazo de dos meses desde que se ha confirmado su situación de insolvencia. Como he defendido antes, las demandas extintivas pendientes ante la jurisdicción social anteriores a la solicitud de concurso pueden seguir su tramitación ante el juez de lo social. No solo está en el texto del art. $6410^{\circ}$ de la LC, sino que se

\footnotetext{
${ }^{33}$ Véase la Sentencia del Tribunal Supremo, Sala de lo Social, de 29 de junio de 2017 (ROJ: STS 2899/2017) y la Sentencia del Tribunal Supremo, Sala de lo Social, de 30 de junio de 2017 (ROJ: STS 2904/2017). Véase también la Sentencia del Tribunal Superior de Justicia del País Vasco de 16 de enero de 2018 (ROJ: STSJ PV 210/2018).

${ }^{34}$ Véase la Sentencia del Tribunal Supremo, Sala de lo Social, de 3 de diciembre de 2013, (ROJ: STS 5945/2013). Véase también aplicando la doctrina del TS, la Sentencia del Tribunal Superior de Justicia de Andalucía, Sala de lo Social, de 8 de noviembre de 2017 (ROJ: STSJ AND 11251/2017), donde se enjuicia un caso de impago a la fecha de la demanda alcanzaba las cuatro mensualidades y se dirigía camino de la quinta.

${ }^{35}$ Sentencia del Tribunal Supremo, Sala de lo Social, de 16 de enero de 2015 (ROJ: STS 1208/2015).

${ }^{36}$ Véase la Sentencia del Tribunal Supremo, Sala de lo Social, de 16 de enero de 2015 (ROJ: STS 1208/2015).
} 
evidencia por la propia dinámica de las cosas. El empresario que deja de abonar más de tres mensualidades ha incumplido de forma grave sus obligaciones y el ET lo sanciona con la extinción del contrato y el abono de una indemnización igual a la del despido improcedente. Si el trabajador no puede obtener la extinción indemnizada de su contrato hasta que el impago abarque más de tres mensualidades, momento éste en el que el empresario ya puede solicitar el concurso, por qué debemos premiarlo permitiendo que todas esas demandas, aun siendo anteriores a la solicitud del concurso, se suspendan a la espera de que sea el juez mercantil quién les extinga el contrato con una indemnización sensiblemente inferior. Cosa distinta es que el juez mercantil pueda incluir en el ERE concursal a estos trabajadores, si su contrato no se ha extinguido todavía, pero nada impide que esas demandas continúen ante el juez social. Es cierto que en este punto se produce un punto de conflicto no deseable, esto es, que ambos órdenes jurisdiccionales mantengan la competencia, pero la solución es la reforma legal, pero mientras ello no ocurra, la interpretación de la norma no ofrece dudas. Otra solución sería la de reformular el tema de la culpabilidad y exigir de nuevo dicho requisito ${ }^{37}$, y considerar, por ejemplo, que la solicitud de concurso voluntario elimina la culpabilidad en el impago.

\section{Extinciones individuales por despido tácito}

El concepto o noción de despido tácito viene referido al hecho extintivo de una relación jurídico-laboral por voluntad, claro ésta, del empleador pero que no se ha manifestado formalmente a través de la comunicación escrita que viene exigida en el art. 55 $1^{\circ}$ del Estatuto de los Trabajadores ${ }^{38}$. No cabe confundir, sin embargo, el despido tácito con el despido verbal. En éste, el empresario tampoco ha cumplido la formalidad escrita, pero ha comunicado su decisión extintiva unilateral de forma verbal, de palabra, de modo que el trabajador ha tenido conocimiento preciso de esa voluntad extintiva. En el despido tácito, la voluntad extintiva debe deducirse de hechos concluyentes del empresario, lo cual obliga a indagar acerca de las circunstancias concurrentes a fin de concluir de forma inequívoca que el despido se ha producido ${ }^{39}$.

\footnotetext{
${ }^{37}$ La doctrina Jurisprudencial del Tribunal Supremo, Sala de lo Social, inicia con la sentencia de 24 de marzo de 1992 (ROJ: STS 2533/1992), lo que pudiera denominarse una línea objetiva clara, afirmándose que "la extinción del contrato por la causa del art. 50 del ET no se produce por el dato de que el incumplimiento empresarial sea culpable, sino que la culpabilidad no es requisito para generarlo". Véase la Sentencia del Tribunal Supremo, Sala de lo Social, de 22 de diciembre de 2008 (ROJ: STS 7468/2008), dónde se analiza ese cambio jurisprudencial. Hasta la sentencia de 1992 citada la doctrina era que: "en la aplicación del artículo 50 del Estatuto de los Trabajadores deben ser valoradas las circunstancias concurrentes, por lo que ha de examinarse al igual que en el supuesto de despido del trabajador, si existe incumplimiento contractual grave y culpable".

${ }^{38} \mathrm{El}$ art. $551^{\circ}$ del ET establece que: "el despido deberá ser notificado por escrito al trabajador, haciendo figurar los hechos que lo motivan y la fecha en que tendrá efectos".

${ }^{39}$ La Sentencia del Tribunal Supremo, Sala de lo Social, de 1 de junio de 2004 (ROJ: STS 3753/2004), señala que: "Es también doctrina de esta Sala, no por más antigua menos vigente según la cual sólo puede apreciarse la existencia de un despido tácito a partir de "hechos suficientemente concluyentes a partir de los cuales pueda establecerse la voluntad extintiva del empresario" - SSTS 24 de abril y 17 de julio de 1986, 4 de diciembre de 1989, o 20 de febrero de 1991—, y es a partir de esta apreciación jurisprudencial desde donde alcanzan la relevancia indicada las diferencias antes descritas, pues mientras puede resultar suficientemente concluyente la voluntad empresarial de extinguir la relación laboral en el caso de la sentencia de contraste dado que fue el empresario quien por su propia voluntad cerró la empresa y estaba cerrada ya dos años cuando el trabajador presentó su papeleta de demanda, por el contrario en el caso de la sentencia que se recurre la circunstancia de que el cierre no se produjo por voluntad directa del empresario y el hecho de que la demanda se presentara a los pocos meses avalan la posibilidad de entender que el trabajador no se sintió despedido hasta que presentó la demanda e incluso permiten pensar en la posibilidad de que el empresario — que según los autos estaba en la cárcel— no solo no le hubiera manifestado
} 
Si bien es cierto que la jurisprudencia examina con recelo la figura del despido tácito, también lo es que se acepta por contrariar los principios de la buena fe, básico en las relaciones contractuales, y generar situaciones de inseguridad al trabajador, que nunca deben beneficiar a quien las ha provocado, y por ello su realidad y operatividad no debe excluirse, conforme también constante jurisprudencia, cuando existan hechos que revelen inequívocamente la voluntad empresarial de poner fin a la relación contractual ${ }^{40}$. Caso de no admisión del despido tácito, se llegaría a la paradoja que quien "de hecho" ha sido cesado y no recibe el salario estipulado jamás podría accionar por despi$\mathrm{do}^{41}$.

El cese de la actividad productiva, el no proporcionar ocupación efectiva al trabajador unido al impago de los salarios, el cierre sin previo aviso del centro de trabajo suelen ser las formas más frecuentes de despido tácito y así han venido siendo interpretados por la jurisprudencia unificada, aunque en general, el despido tácito ha sido también identificado simplemente con la falta o incumplimiento de las formalidades legales ${ }^{42}$.

De entre todas las formas de despido tácito interesa especialmente la que deriva del cierre o cese de actividad empresarial en general y muy especialmente en situación de concurso, debiendo añadirse que el cierre empresarial que justifica la existencia de un despido tácito debe obedecer a la voluntad del empresario, y aún más, se ha dicho a una voluntad directa del empresario y en caso contrario, esto es, en aquellos casos en que el cierre empresarial no obedece a esa voluntad directa, o simplemente es ajena a su voluntad, entonces no podemos estar en presencia de un despido tácito ${ }^{43}$. Lo anterior tiene especial importancia en situación de concurso como veremos a continuación.

En el ordenamiento jurídico español, la única posibilidad prevista legalmente de cese de actividad por decisión judicial está contemplada en la LC en su art. $444^{\circ}$. Debe ser destacable al respecto, la modificación del referido precepto de la LC efectuada por la última reforma de la Ley Concursal operada por la Ley 38/2011. En efecto, si bien el párrafo $1^{\circ}$ del art. $444^{\circ} \mathrm{LC}$ se mantiene en los mismos términos que antes, esto es, que el juez del concurso podrá "acordar mediante auto el cierre de la totalidad o de parte de las oficinas, establecimientos o explotaciones de que fuera titular el deudor, así como cuando ejerciera una actividad empresarial, el cese o la suspensión, total o parcial,

al actor su voluntad de extinguir el contrato sino su esperanza de reanudar la actividad empresarial y la relación laboral entre ambos”.

${ }^{40}$ Véase, por todas, la Sentencia del Tribunal Superior de Justicia de Castilla la Mancha de 29-10-2008 (Recurso $n^{0}$ 726/08).

${ }^{41}$ Cfr. con la Sentencia del Tribunal Supremo, Sala de lo social, de 4 de diciembre de 1989 (ROJ: STS 7011/1989).

${ }^{42} \mathrm{Al}$ respecto de todo lo anterior, véase la Sentencia del Tribunal Supremo, Sala de lo social, de 9 de octubre de 2009 (ROJ: STS 7179/2009).

${ }^{43}$ En tal sentido, la Sentencia del Tribunal Supremo, Sala de lo Social, de 23 de marzo de 1990 (ROJ STS 17681/1990) determinó que "En efecto, no puede valer como tal despido tácito o por hechos concluyentes el cierre y precintaje (temporal y provisional) del centro de trabajo de 'Tecnimarsa' (14 de marzo de 1988), que es un acto decretado por la autoridad y no por el empleador; no es despido tácito tampoco, por razones obvias, la petición de 'Tecnimarsa' a la autoridad laboral de autorización de extinción de las relaciones de trabajo (17 de marzo de 1988), momento inicial de un expediente de regulación de empleo que no prosperó. En realidad, sólo podría haber habido despido tácito en las circunstancias del caso enjuiciado a partir de la notificación al empleador del acuerdo de denegación de tal petición por parte de la autoridad laboral; notificación que, según el hecho probado cuarto tuvo lugar el 26 de abril de 1988”. 
de ésta”, incorpora como novedad la que se halla en el párrafo $2^{\circ}$ cuando establece que: "Cuando las medidas supongan la extinción, suspensión o modificación colectivas de los contratos de trabajo, incluidos los traslados colectivos, el juez actuará conforme a lo establecido en el artículo $82^{\circ}$ y simultáneamente iniciará el expediente del art. 64". De este modo, la legislación española exige que deba seguirse el procedimiento de regulación de empleo, el expediente concursal del art. 64 de la LC, con autorización incluida del juez del concurso ${ }^{44}$.

Además, con la modificación operada con la reforma, se incrementan las garantías de los trabajadores, si tenemos en cuenta que lo que trata de evitar la norma es que se produzca el cierre del establecimiento empresarial o el cese de la actividad empresarial sin que al mismo tiempo se hayan extinguido los contratos de trabajo afectados por ellos. Y ello porque la LC prevé, por un lado, un procedimiento, normalmente el incidente concursal general, para la solicitud y obtención de dicha autorización de cierre o cese de actividad y por otro, en el caso de que ello conlleve la extinción colectiva de contratos de trabajo (u otras medidas colectivas), el procedimiento de extinción colectiva prevista en el art. 64 de la misma LC que finaliza con el Auto del Juez del Concurso extinguiendo los contratos de trabajo. Antes de la reforma, la ausencia del adverbio “simultáneamente”, traía como consecuencia que ambos procedimientos no tenían por qué coincidir en el tiempo y por ello, existía la posibilidad de que se hubiera autorizado el cierre o cese de actividad y que, sin embargo, la extinción colectiva de los contratos no hubiera sido autorizada, de modo que los trabajadores podrían entender que estaban siendo despedidos aún de forma tácita y accionar por despido.

En la actualidad, el inicio simultaneo de ambos expedientes debe garantizar que las resoluciones judiciales que respectivamente recaigan en cada uno de ellos sea también simultánea a lo que también ayudará la posibilidad que ahora contempla el art. $648^{\circ}$ de la LC, tras la reforma, de que el auto de extinción fije una fecha de efectos posterior a la propia fecha del auto impidiendo así cualquier resquicio a los trabajadores para accionar por despido (tácito), amén de racionalizar la medida de cierre o cese de actividad en el sentido de que no se sigan generando créditos salariales cuando la empresa ya no tiene actividad o ha cerrado ${ }^{45}$.

Si la empresa no cumple las exigencias del art. 44 de la LC, estaríamos ante la figura de un despido tácito de carácter colectivo y los trabajadores tienen a su disposición el procedimiento de despido individual para demandar a la empresa alegando haber sido objeto de despido, o incluso la de un despido colectivo nulo. Tras la reforma de la Ley concursal por la Ley 38/2011, es bastante claro que la acción de despido será la

\footnotetext{
${ }^{44}$ Recordemos que La Directiva 1975/129/CEE de 17 de febrero de 1975 sobre despidos colectivos, no se aplicó inicialmente a "los trabajadores afectados por el cese de actividades del centro de trabajo cuando éste resulte de una decisión judicial”, lo que luego fue objeto de modificación, pues la Directiva de 1975 fue modificada por la Directiva 92/56, entre otros extremos, en lo relativo a la supresión del supuesto de inaplicación inicialmente previsto referente a los trabajadores afectados por el cese de actividades del centro de trabajo cuando éste (cese) resulte de una decisión judicial, aunque con la posibilidad de que, sin embargo, el procedimiento de despido colectivo en lo que viene referido a la notificación a la autoridad laboral no fuera aplicable (o lo que es lo mismo, que los Estados miembros no están obligados a aplicar dicho requisito) en el caso de despidos colectivos producidos por el cese de las actividades del establecimiento por decisión judicial .

${ }^{45}$ Estas dos grandes diferencias implican que en situación concursal, precisamente, por el contrario de lo que señala la Directiva Comunitaria, existan más obligaciones a cumplir por el empresario y más garantías para los trabajadores que en situación extra concursal.
} 
utilizada en mayor medida teniendo en cuenta que la alternativa a ella, la acción extintiva ex art. 50 del ET podrá quedar paralizada o suspendida. Pero esta acción, que también es individual, tiene el mismo régimen jurídico que el de la acción extintiva del art. 50 del ET, esto es, nada impide que el juez mercantil incluya al trabajador que accionó por despido tácito y que por tanto, se desestime su demanda por el juez social, al haber sido ya previamente extinguida ${ }^{46}$. En ese sentido, el que sea una acción de despido, y no una acción extintiva del art. 50 no impide la aplicación analógica del precepto, al estar motivada también por la situación económica o de insolvencia de la concursada.

De todas formas, en situación de concurso, la apreciación de la figura del despido tácito ya se vino restringiendo, al contrario de lo que sucedía si la empresa no había instado la declaración de concurso y se limitaba simplemente a dejar de pagar los salarios y dar ocupación a sus trabajadores, pues no solía apreciarse tal voluntad extintiva, precisamente por la situación concursal. También se detectó cierta tendencia a no apreciar gravedad suficiente para extinguir el contrato de trabajo con amparo en el art. 50 del ET, precisamente atendiendo a la situación concursal de la empresa lo que vino a indicar una progresiva tendencia a analizar la culpabilidad empresarial, sin que ello se haya consolidado ${ }^{47}$.

En ese sentido, a los efectos de determinar las consecuencias de la presentación de una demanda por despido tácito, singular o plural, por un grupo de trabajadores motivada por la situación económica o de insolvencia del empleador por hechos acontecidos antes de la solicitud de declaración de concurso, con demanda ante el Juez de lo Social anterior a la fecha de tal solicitud de concurso, el TS ha declarado correcta la actuación del Juez Mercantil, y efectuada dentro de sus competencias, de declarar la extinción colectiva de los contratos de trabajo de aquellos trabajadores que formularon la demanda de despido tácito motivada por la situación económica del empleador por hechos anteriores a la solicitud de declaración del concurso, aunque la presentación de la demanda de despido se hubiere efectuado antes de tal fecha y se encontrara el proceso social en tramitación en el momento de la declaración del concurso, con sustento en la vis atractiva del concurso con el objeto de no defraudar la finalidad de su procedimiento ${ }^{48}$.

\section{Extinciones individuales y grupo de empresas}

\section{A. Concepto de grupo}

\footnotetext{
46 Véase la Sentencia del Tribunal Supremo, Sala de lo Social, de 30 de junio de 2017 (ROJ: STS 2904/2017).

47 Véase la Sentencia del Tribunal Superior de Justicia de Galicia, Sala de lo Social, de 22 de diciembre de 2010 (ROJ: STSJ GAL 11807/2010); y otra de la misma Sala de Galicia, de 30 de abril de 2012 (ROJ: STSJ GAL 4236/2012) con cita en la Sentencia del Tribunal Superior de Justicia de Cataluña, Sala de lo Social, de 3 de febrero de 2010 (ROJ: STSJ CAT 1381/2010), dónde se afirma que la actuación de la empresa debe ser analizada dentro de la situación concurrente, cual es la crisis económica de la empresa, manifestada por la presentación y admisión del concurso de acreedores, lo que permite concluir que la actuación empresarial no es caprichosa ni obedece, en principio, a oscuros intereses, sino que trae causa de una situación de crisis objetiva frente a la cual la empresa ha reaccionado con los medios que el derecho pone a su alcance, como es la solicitud de la extinción colectiva de contratos en el seno de un procedimiento concursal derivado de la situación económica de la empresa, lo que implica evidentemente que el motivo de falta de ocupación efectiva de los trabajadores tienen su origen en causas objetivas y no en el capricho de la empresa.

48 Véase la Sentencia del Tribunal Supremo, Sala de lo Social, de 13 de abril de 2016 (ROJ: STS 1821/2016)
} 
Un problema muy recurrente se produce en relación al concepto de grupo de empresas laboral o patológico ${ }^{49}$. Un grupo mercantil es lícito, de modo que el mero hecho de que dos o más empresas pertenezcan al mismo grupo empresarial no es suficiente para derivar de ello, sin más, una responsabilidad solidaria respecto de obligaciones contraídas por una de ellas con sus propios trabajadores, sino que es necesaria, además, la presencia de elementos adicionales, porque los componentes del grupo tienen en principio un ámbito de responsabilidad propio como personas jurídicas independientes que son; elementos que convierten al grupo mercantil lícito, en otro que no lo es, y que se ha dado en llamar grupo de empresas laboral o patológico ${ }^{50}$.

La enumeración — en manera alguna acumulativa — de los elementos adicionales que determinan la responsabilidad de las diversas empresa del grupo es la que sigue: $1^{\circ}$ ) el funcionamiento unitario de las organizaciones de trabajo de las empresas del grupo, manifestado en la prestación indistinta de trabajo -simultánea o sucesivamente- en favor de varias de las empresas del grupo; $2^{\circ}$ ) la confusión patrimonial; $3^{\circ}$ ) la unidad de caja; $4^{\circ}$ ) la utilización fraudulenta de la personalidad jurídica, con creación de la empresa "aparente"; y $5^{\circ}$ ) el uso abusivo — anormal— de la dirección unitaria, con perjuicio para los derechos de los trabajadores.

En todo caso, el concepto de grupo laboral de empresas y, especialmente, la determinación de la extensión de la responsabilidad de las empresas del grupo depende de cada una de las situaciones concretas que se deriven de la prueba que en cada caso se haya puesto de manifiesto y valorado, sin que se pueda llevar a cabo una relación numérica de requisitos cerrados para que pueda entenderse que existe esa extensión de responsabilidad $^{51}$.

Conviene precisar al respecto, que el grupo de sociedades, que no parece acertado identificar sin más con el concepto de "unidad de empresa" al que alude el párrafo tercero del art. 64.5 de la LC, no puede ser declarado en concurso ya que éste ha de referirse a una persona natural o jurídica (art. 1.1 LC) y el grupo, que ni siquiera puede ser deudor como tal, no lo es.

\section{B. Grupo de empresas dentro del concurso}

Con anterioridad a la reforma de la LC del año 2011, el art. 64 no permitía introducir en el seno del ERE concursal la cuestión relativa a la existencia de un grupo de empresas, lícito o no, es decir, que la empresa concursada junto con otras, no declaradas

\footnotetext{
${ }^{49}$ La Sentencia del Tribunal Supremo, Sala de lo Social, del 20 de junio de 2018 (ROJ: STS 2601/2018), realiza una precisión terminológica sobre el concepto de "grupo de empresas", indicativa de que "la expresión 'grupo patológico' ha de ser reservada para los supuestos en que las circunstancias determinantes de la responsabilidad solidaria se enmarcan en el terreno de la ocultación o fraude, pero cuando los datos objetivos que llevan a esa responsabilidad laboral no se ocultan, no responden a una actuación con finalidad defraudatoria ni atienden a abuso alguno, la terminología más adecuada más bien debiera ser la de 'empresa de grupo' o 'empresa-grupo', que resultaría algo así como el género del que aquél —el grupo patológico - es la especie, cualificada precisamente por los referidos datos de abuso, fraude u ocultación a terceros".

${ }^{50}$ Véase la Sentencia del Tribunal Supremo, Sala de lo Social, de 11 de julio de 2018 (ROJ: STS 3303/2018).

${ }^{51}$ Véase la Sentencia del Tribunal Supremo, Sala de lo Social, de 8 de noviembre de 2017 (ROJ: STS 4216/2017).
} 
en concurso, conformaban una unidad empresarial que, frente al trabajador, podría considerarse un solo empleador. Ello dio pie a que los trabajadores, aun habiendo sido extinguido su contrato a medio de auto por el juez del concurso a través del procedimiento del art. 64, plantearan demandas ante el juez de lo social por despido improcedente pretendiendo una mayor indemnización en base a la existencia de ese grupo, lo que en algunos casos fue admitido.

En la actualidad, la incompetencia del orden social en estos casos ha sido la doctrina judicial mayoritaria ${ }^{52}$, confirmada por la Jurisprudencia del $\mathrm{TS}^{53}$. Y es que, al margen de que un contrato ya extinguido en el seno del concurso por el juez mercantil no pueda volver a ser extinguido, es lo cierto que tras la modificación operada por la Ley 38/2011, de 10 de octubre, el art. $645^{\circ}$ LC permite expresamente que los representantes de los trabajadores o la administración concursal soliciten al juez «la participación en el período de consultas de otras personas físicas o jurídicas que indiciariamente puedan constituir una unidad de empresa con la concursada. A estos efectos, podrán interesar el auxilio del juzgado que se estime necesario para su comprobación. Igualmente, para el caso de unidad empresarial, y a efectos de valorar la realidad económica del conjunto empresarial, se podrá reclamar la documentación económica consolidada o la relativa a otras empresas».

Ello supone que la cuestión de la existencia de un grupo de empresas puede y debe- ser suscitada en ese momento procesal, ante el juez del concurso y que, en todo caso, la vía para poner en cuestión la acomodación a Derecho de la decisión extintiva autorizada por el Auto de lo mercantil se ciñe a la interposición del recurso de suplicación frente a dicho Auto $— 0$ a la impugnación individual a través del incidente concursal, si hubiere mérito para ello-.

En definitiva, cuando se quiere cuestionar la validez de la extinción acordada en el seno del concurso hay que accionar (individual o colectivamente) ante el Juzgado de lo Mercantil. Eso es así incluso si se desea plantear la existencia de un posible fenómeno empresarial de agrupación. Cosa distinta es que no se cuestiona la validez del despido o extinción concursal, sino que se reclama el abono de determinadas cantidades derivadas de la extinción contractual concursal (sean indemnizatorias o retributivas), lo que comporta que la solución deba ser la opuesta. La competencia exclusiva del Juez Mercantil desaparece cuando se trata de una reclamación laboral dirigida frente a la concursada junto con otros que no son sujetos concursados, pues la acción ejercitada, de ser estimada, llevaría aparejada la condena de diversos sujetos que no son parte en el procedimiento concursal $^{54}$. La excepcionalidad de la atribución competencial en favor

\footnotetext{
${ }^{52}$ Véase la Sentencia del Tribunal Superior de Justicia de Galicia, Sala de lo Social, del 29 de septiembre de 2014 (ROJ: STSJ GAL 7322/2014), dónde se trata del caso de un trabajador que vio extinguido su contrato de trabajo en virtud del llamado "ERE concursal” y con posterioridad interpone demanda frente a la concursada y otras sosteniendo la existencia de grupo de empresas y reclamando la indemnización correspondiente al despido improcedente.

${ }^{53}$ Véase la Sentencia del Tribunal Supremo, Sala de lo Social, de 8 de marzo de 2018 (ROJ: STS 989/2018), dónde se trata del caso de trabajadores que vieron extinguidos sus contratos de trabajo en virtud del llamado "ERE concursal" y con posterioridad interponen demanda frente a la concursada y otras sosteniendo la existencia de grupo de empresas y reclamando la indemnización correspondiente al despido improcedente.

${ }^{54}$ Véase el Auto del Tribunal Supremo, Sala Especial de Conflictos de Competencia, de 9 de marzo de 2016 (ROJ: ATS 2647/2016).
} 
del Juez del Concurso juega en favor de la jurisdicción social cuando no aparezca una norma explícita que le asigne el conocimiento de determinado asunto" 55 .

De este modo, aquellas demandas individuales por despido tácito, o extinción, dirigidas frente a la concursada y frente a empresas respecto de las que está pendiente resolver en el ERE concursal seguido ante el Juzgado mercantil, la misma cuestión de grupo de empresas, esto es, si se integran o no en relación de grupo de empresas laboral con la concursada, habrían de resolverse por el Juez Mercantil, de conformidad con el art.64.8 LC, por los trámites del incidente concursal de los arts.192 a 196 LC, conforme señala el art.195 LC ${ }^{56}$.

\section{EXTINCIONES INDIVIDUALES EN SITUACIÓN DE PRECONCURSO}

El art. 5 bis de la LC regula el llamado preconcurso en virtud del cual el deudor puede poner en conocimiento del juzgado competente para la declaración de su concurso (juzgado mercantil) que ha iniciado negociaciones para alcanzar un acuerdo de refinanciación de los previstos en el artículo 71 bis.1 y en la Disposición adicional cuarta, o para obtener adhesiones a una propuesta anticipada de convenio en los términos previstos en esta Ley $^{57}$.

Esta comunicación podrá formularse en cualquier momento antes del vencimiento del plazo establecido en el artículo 5, que es el plazo para solicitar la declaración de concurso (dos meses siguientes a la fecha en que hubiera conocido o debido conocer su estado de insolvencia).

La comunicación de preconcurso permite al deudor, durante tres meses, eximirse de pedir la declaración de concurso voluntario (y que tampoco nadie la pueda pedir conforme dispone el art. 153 de la LC), y negociar un acuerdo de refinanciación, o conseguir las adhesiones necesarias para la admisión a trámite de una propuesta anticipada de convenio, pero transcurridos tres meses desde esa comunicación al juzgado, el deudor, haya o no alcanzado dichos acuerdos deberá solicitar la declaración de concurso dentro del mes hábil siguiente, a menos que ya lo hubiera solicitado el mediador concursal (en el caso del acuerdo extrajudicial de pagos que a continuación veremos), o no se encontrara en estado de insolvencia.

Nada impide que mientras negocia o intenta obtener una refinanciación el impago de salarios continúe, y que los trabajadores demanden la extinción de su contrato. De este modo si bien queda paralizado el plazo para solicitar concurso voluntario por

\footnotetext{
55 Véase la Sentencia del Tribunal Supremo, Sala de lo Social, de 6 de junio de 2018 (ROJ: STS 2258/2018), con cita en el auto 1/2016, de 19 de marzo, de la Sala Especial de Conflictos de Competencia (ROJ: ATS 2647/2016), dónde se concluye que: 1) El Juez de lo Mercantil es competente para conocer del despido acordado en el seno del concurso, incluso si se plantea la posibilidad de existencia de un grupo empresarial; 2) Si se reclama el abono de determinadas cantidades derivadas de la extinción contractual, la competencia del Juez de lo Mercantil desaparece cuando la reclamación se dirige frente a quienes no son sujetos concursados y no corresponde al juez del concurso conocer de la pretensión cuando la demanda se presenta frente a empresas concursada y otras que no lo están.

56 Véase el art. 195 de la LC.

${ }^{57}$ Conforme al art. 5 bis $1^{\circ}$ segundo párrafo de la LC, lo mismo para "el caso de caso en que solicite un acuerdo extrajudicial de pago, una vez que el mediador concursal propuesto acepte el cargo, el registrador mercantil o notario al que se hubiera solicitado la designación del mediador concursal deberá comunicar, de oficio, la apertura de las negociaciones al juzgado competente para la declaración de concurso”.
} 
parte del empresario que ha dejado de pagar salarios, no así la acción extintiva de los trabajadores. Como ya se ha dejado escrito, solo en situación concursal es posible plantear el procedimiento de extinción colectiva de contratos de trabajo al amparo del art. 64 de la LC, nunca en situación de preconcurso. En ese caso habrá que acudir al procedimiento de despido colectivo, aplicándose el régimen previsto en el ET (art. 51), o a los despidos objetivos (arts. 52 y 53 del ET), pero, aquellas demandas individuales de extinción al amparo del art. $501^{\circ}$ b) del ET seguirán su curso, con la consiguiente sentencia, en su caso extintiva, sin suspensión ni ningún obstáculo para su continuidad.

La única consecuencia importante para los trabajadores de esta comunicación de preconcurso es la de que "no podrán iniciarse ejecuciones judiciales o extrajudiciales de bienes o derechos que resulten necesarios para la continuidad de la actividad profesional o empresarial del deudor, hasta que se produzca determinadas circunstancias"58, y, por otro lado, que "las ejecuciones de dichos bienes que estén en tramitación se suspenderán por el juez que estuviere conociendo de las mismas con la presentación de la resolución del secretario judicial dando constancia de la comunicación”, de manera que la ejecución de los créditos salariales e indemnizatorios derivados de dichas resoluciones judiciales extintivas de los contratos de trabajo no podrá iniciarse, y si lo habían hecho se suspenderán.

La comunicación de preconcurso es pública, salvo que el deudor solicite el carácter reservado de la misma, lo que propicia que los trabajadores la conozcan y apuren la posibilidad de plantear la extinción indemnizada de sus contratos con una indemnización mayor ante la eventualidad de la declaración de concurso. Ello significa que la situación de preconcurso puede ser perjudicial para el deudor concursado, quién por un lado puede obtener una refinanciación, pero por otro se puede ver abocado a indemnizaciones mayores para extinguir los contratos laborales, sin perjuicio de que acuda al despido colectivo, o al despido individual por causas objetivas, cuya indemnización es la misma que para la extinción en el ERE concursal ${ }^{59}$.

En este punto resulta de especial importancia la doctrina judicial ya mencionada conforme a la cual todas estas acciones extintivas, con independencia del momento en el que se hayan planteado, antes o después de la solicitud de concurso, pueden ser reconvertidas en colectivas, a los efectos de su extinción por el juez mercantil. La co-

\footnotetext{
${ }^{58}$ Estas circunstancias son: a) Se formalice el acuerdo de refinanciación previsto en el artículo 71 bis.1; b) se dicte la providencia admitiendo a trámite la solicitud de homologación judicial del acuerdo de refinanciación; c) se adopte el acuerdo extrajudicial de pagos; d) se hayan obtenido las adhesiones necesarias para la admisión a trámite de una propuesta anticipada de convenio; e) o tenga lugar la declaración de concurso.

${ }^{59}$ Por lo que se refiere a los retrasos que pueden justificar una estimación de la acción extintiva, véase la Sentencia del Tribunal Supremo, Sala de lo Social, de 5 de junio de 2018 (ROJ: STS 2357/2018), en la que se establece que: “... revisten la entidad suficiente para decretar la resolución indemnizada del contrato de trabajo los retrasos producidos durante un lapso ininterrumpido de nueve meses, con un tiempo de demora variable de entre 8 y 17 días, y un retardo promedio de 13,5 días (Sentencia del Tribunal Supremo, Sala de lo Social de 3 de diciembre de 2012, ROJ: STS 8754/2012), o a lo largo de 14 meses consecutivos, con una dilación de entre 3 y 28 días, y una media aproximada de 11 días por mes (Sentencia del Tribunal Supremo, Sala de lo Social de 24 de septiembre 2013, ROJ: STS 5153/2013); o en un período continuado de 15 meses, oscilando el retraso entre 15 y alcanzando un promedio de 22,5 días (Sentencia del Tribunal Supremo, Sala de lo Social de 16 julio 2013, ROJ: STS 4358/2013); o el mantenido durante 26 meses consecutivos, con una tardanza mínima de 2 días y máxima de 26 días, con prevalencia de la situada en 12 días, siendo el retraso promedio de 11,20 días (Sentencia del Tribunal Supremo, Sala de lo Social de 22 de diciembre de 2008, ROJ: STS 7468/2008)”.
} 
municación de preconcurso puede propiciar la presentación de demandas extintivas individuales, animada por el hecho de que serían demandas anteriores a la solicitud de concurso; argumento éste que ha sido utilizado para considerar que todas ellas son colectivas desde el momento en que se inicia el ERE concursal. Ya he dicho que no se cuestiona en este trabajo la posibilidad, llegado el caso, de que el juez del concurso pueda extinguir los contratos de todos los trabajadores de la empresa, incluidos los de aquellos que plantearon la demanda extintiva antes de la solicitud del concurso. Lo que defiendo es la competencia del juez social para seguir tramitando esas demandas, al ser anteriores a la solicitud del concurso, y no estar afectadas por la suspensión, es decir, que ambos sigan en la carrera cuya meta es la extinción de los contratos laborales.

\section{EXTINCIONES INDIVIDUALES EN EL CASO DE ACUERDO EXTRAJUDICIAL DE PAGOS}

Figura diferente al preconcurso es el acuerdo extrajudicial de pagos regulado en el Título X de la LC (arts. 231 a 242 bis), si bien esta figura solo se aplica al deudor personal natural empresario (se incluyen los autónomos), y a personas jurídicas, sean o no sociedades de capital siempre que se encuentren en situación de insolvencia y que en caso de ser declaradas en concurso, el mismo no hubiere de revestir especial complejidad en los términos previstos en el art. 190 de la $\mathrm{LC}^{60}$, y que, en tercer lugar, dispongan de activos suficientes para satisfacer los gastos propios del acuerdo ${ }^{61}$.

El art. 231 de la LC permite esta posibilidad de iniciar un procedimiento para alcanzar un acuerdo extrajudicial de pagos con sus acreedores, siempre que la estimación inicial del pasivo no supere los cinco millones de euros. En el caso de deudor persona natural empresario, deberá aportarse el correspondiente balance.

El procedimiento implica el nombramiento de un mediador concursal, quién comprueba la documentación, la existencia y la cuantía de los créditos y es quién convoca al deudor y a los acreedores que figuren en la lista presentada por el deudor o de cuya existencia tenga conocimiento por cualquier otro medio a una reunión que se celebrará dentro de los dos meses siguientes a la aceptación de su cargo, en la localidad donde el deudor tenga su domicilio. Se excluirá en todo caso de la convocatoria a los acreedores de derecho público.

Los principales efectos de la iniciación del expediente conforme al art. 235 de la LC es que, si bien el deudor podrá continuar con su actividad laboral, empresarial o profesional, desde la presentación de la solicitud, se abstendrá de realizar cualquier acto de administración y disposición que exceda los actos u operaciones propias del giro o tráfico de su actividad.

\footnotetext{
${ }^{60}$ Conforme al art. 190 de la LC: "El juez podrá aplicar el procedimiento abreviado cuando, a la vista de la información disponible, considere que el concurso no reviste especial complejidad, atendiendo a las siguientes circunstancias:

1. ${ }^{\circ}$ Que la lista presentada por el deudor incluya menos de cincuenta acreedores.

2. ${ }^{\circ}$ Que la estimación inicial del pasivo no supere los cinco millones de euros.

3. ${ }^{\circ}$ Que la valoración de los bienes y derechos no alcance los cinco millones de euros.

Cuando el deudor sea una persona natural el juez valorará especialmente si responde o es garante de las deudas de una persona jurídica y si es administrador de alguna persona jurídica”.

${ }^{61}$ Véase el art. $2311^{\circ}$ y $2^{\circ}$ de la LC.
} 
Y por lo que se refiere a los trabajadores, desde la comunicación de la apertura de las negociaciones al juzgado competente para la declaración del concurso: a) no podrán iniciar ni continuar ejecución judicial o extrajudicial alguna sobre el patrimonio del deudor mientras se negocia el acuerdo extrajudicial hasta un plazo máximo de tres meses. Se exceptúan los acreedores de créditos con garantía real, que no recaiga sobre bienes o derechos que resulten necesarios para la continuidad de la actividad profesional o empresarial del deudor ni sobre su vivienda habitual. Cuando la garantía recaiga sobre los bienes citados en el inciso anterior, los acreedores podrán ejercitar la acción real que les corresponda frente a los bienes y derechos sobre los que recaiga su garantía sin perjuicio de que, una vez iniciado el procedimiento, quede paralizado mientras no hayan transcurrido los plazos previstos en este apartado.

Practicada la correspondiente anotación de la apertura del procedimiento en los registros públicos de bienes, no podrán anotarse respecto de los bienes del deudor instante embargos o secuestros posteriores a la presentación de la solicitud del nombramiento de mediador concursal, salvo los que pudieran corresponder en el curso de procedimientos seguidos por los acreedores de derecho público.

De este modo, este procedimiento en nada impide el ejercicio de las acciones encaminadas a la extinción de los contratos, en los mismos términos que hemos visto en situación de preconcurso.

\section{EXTINCIONES INDIVIDUALES EN SITUACIÓN DE CONCURSO SOBREVENIDO}

Podemos hablar de concurso sobrevenido en relación a demandas extintivas al amparo del art. 50 del ET, previamente existentes en los juzgados de lo social, en cuyo caso me remito a todo cuanto se ha dicho anteriormente en relación a demandas anteriores o posteriores a la solicitud del concurso. Si las demandas pendientes son de despido, al amparo del art. 52 del ET, la competencia seguirá en la jurisdicción social.

También podemos hablar de concurso sobrevenido en relación a una previa situación de preconcurso, en el caso de que finalmente la declaración de concurso sea pedida por los acreedores o el propio deudor. La declaración de concurso, entonces, tiene sus propios efectos, con independencia de haber existido con carácter previo una situación de preconcurso. En ese sentido la única ventaja es para el deudor, ya que la comunicación de preconcurso puede servir para considerarla como una solicitud de concurso anterior a la de sus acreedores, lo que permitirá que se declare el mismo como voluntario.

En el caso de que el empresario deudor haya seguido un procedimiento e expediente extrajudicial de pagos y se haya incumplido, o bien no haya conseguido alcanzar el acuerdo, es el mediador quién insta el concurso del empresario. Al respecto, el art. 234 de la LC lo denomina concurso consecutivo, señalando que " 1 . Tendrá la consideración de concurso consecutivo el que se declare a solicitud del mediador concursal, del deudor o de los acreedores por la imposibilidad de alcanzar un acuerdo extrajudicial de pagos o por su incumplimiento”, y que “Igualmente tendrá la consideración de concurso consecutivo el que sea consecuencia de la anulación del acuerdo extrajudicial alcanzado". 
Como el acuerdo extrajudicial solo pudo tramitarse en el caso de personas jurídicas que llegado el caso el trámite sea el de concurso abreviado, el concurso consecutivo se regirá lógicamente también por lo dispuesto para el procedimiento abreviado con ciertas especialidades, que en nada afectan a las posibles acciones extintivas de los trabajadores $^{62}$.

También debe hacerse referencia a cuando el concurso sobreviene cuando habían planteado acciones individuales de extinción, y al tiempo el empresario había iniciado período de consultas con sus trabajadores a los efectos de un despido colectivo.

En una situación extraconcursal, la convivencia entre las acciones individuales y el procedimiento de despido colectivo es pacífica, sin perjuicio de que esté también vigente la regla según la cual un contrato no puede ser extinguido dos veces, de modo que la tramitación de un procedimiento de despido colectivo (PDC) no obliga a la suspensión de las demandas individuales de extinción. Ambos procedimientos podrán seguir, y llegado el caso, si el PDC culmina con el despido (individual) de esos mismos trabajadores, lo que sería un despido objetivo del art. 52 del ET, podrán acumularse ambas demandas, salvo que el juez de lo social haya ya extinguido, pero sin que se vea obligado, por el contrario, a suspender las demandas por el hecho de que se haya iniciado dicho PDC. En estos casos de acumulación de acciones, si la causa o hecho base de las mismas son independientes rige un criterio cronológico sustantivo no excluyente, que da prioridad al análisis y resolución de la acción que haya nacido antes, atendiendo al hecho constitutivo de la misma, si bien su éxito no impedirá el examen, y decisión en su caso, de la otra acción ${ }^{63}$.

En caso de crisis empresarial, sin embargo, lo más probable es que ambas acciones se sustentan en hechos que deriven de la misma situación económica negativa, por ejemplo, el impago de salarios como hecho base de la acción extintiva, y la propia situación económica negativa en el caso del despido, lo que plantea la duda de cuál es el hecho al que debe darse prioridad antes.

En estos casos el criterio a aplicar es el criterio cronológico procesal no excluyente, que no prescinde de la doble solución. Ello significa que cuando las dos acciones que se ejercitan están fundadas en las mismas causas o en una misma situación de conflicto, la sentencia de instancia debe analizar conjuntamente ambas acciones y las conductas subyacentes; pero que ello no quiere decir que haya de decidirse las dos acciones a la vez, sino que la sentencia debe dar repuesta en primer lugar a la que acción que se haya planteado antes, y esté en la base de la situación del conflicto siempre y luego habrá de pronunciarse también sobre la segunda acción y emitir el pronunciamiento correspondiente para determinar las indemnizaciones, en caso de que éstas procedan ${ }^{64}$.

\footnotetext{
${ }^{62}$ Véase el art. $2422^{\circ}$ de la LC.

${ }^{63}$ Este criterio es aplicado por primera vez en la Sentencia del Tribunal Supremo, Sala de lo Social, de 25 de enero de 2007 (ROJ: STS 1744/2007), en un caso dónde la acción extintiva estaba basada en el impago de salarios y falta de ocupación efectiva producida desde agosto y septiembre, respectivamente, y por otro, un despido disciplinario.

${ }^{64}$ Véase el caso de la Sentencia del Tribunal Supremo, Sala de lo Social, de 21 de septiembre de 2016 (ROJ: STS 4442/2016), en un caso de las acciones de extinción contractual y de despido están estrechamente vinculadas y que la base del conflicto no es otra que la situación negativa de la empresa, pues la empresa había notificado a los trabajadores su intención de iniciar un procedimiento de despido colectivo el día 11-10-2013, mientras que la papeleta de conciliación por la acción extintiva por impago de salarios se presenta el 8-10-2013 (tres días antes). La sentencia de instancia, después confirmada por la de Supli-
} 
Por último, ¿qué ocurre si hallándose en trámite un PDC, la empresa es declarada en concurso? A tal efecto, el art. 64 de la LC establece que "si a la fecha de la declaración del concurso estuviere en tramitación un procedimiento de despido colectivo o de suspensión de contratos o reducción de jornada, la autoridad laboral remitirá lo actuado al juez del concurso. Dentro de los tres días siguientes al de recepción del expediente, el secretario judicial citará a comparecencia a los legitimados previstos en el apartado siguiente para exponer y justificar, en su caso, la procedencia de continuar con la tramitación de las medidas colectivas, conforme a lo previsto en este artículo. Las actuaciones practicadas en el procedimiento administrativo anterior hasta la fecha de la declaración de concurso conservarán su validez en el procedimiento que se tramite ante el juzgado", y en un segundo párrafo que: “Si a la fecha de la declaración del concurso el empresario ya hubiera comunicado a la autoridad laboral la decisión adoptada al amparo de lo establecido en los artículos 51 o 47 del Estatuto de los Trabajadores o, en su caso, ya hubiera recaído resolución administrativa autorizando medidas de extinción, suspensión o reducción de jornada, corresponderá a la administración concursal la ejecución de tales medidas. En todo caso, la declaración de concurso ha de ser comunicada a la autoridad laboral a los efectos que procedan”.

El precepto no ha sido reformado atendido el hecho de que en la actualidad el PDC no requiere de autorización judicial, pues la misma desapareció con la reforma laboral del año $2012^{65}$, pero mutandis mutandi, cabe entender que desde la declaración de concurso, el PDC debe ser remitido al juzgado mercantil, dónde se dará audiencia a las partes a los efectos de decidir la continuidad o no del expediente. Si se decide su continuidad, todo lo tramitado antes tendrá eficacia, de modo que podrá actuar la conversión en colectivas de las demandas extintivas individuales conforme establece el art. 6410 de la LC.

\section{BIBLIOGRAFÍA}

RODRÍGUEZ ACHUTEGUI, E.: "Reforma del sistema de relaciones laborales y concurso”, Madrid: Consejo General del Poder Judicial, 2012 (Cuadernos Digitales de Formación 41).

cación, había declarado probado que la acción extintiva fue formulada después de que la empresa les hubiera notificado su intención de iniciar un procedimiento de despido colectivo el día 11-10-2013, con la finalidad — decía — de conseguir una mayor indemnización que la que les correspondería por el despido objetivo, pero acreditado que fu antes el TS revoca y estima la acción extintiva, manteniendo la procedencia del despido objetivo (por causas económicas) que se declaró en la instancia.

65 Primero con el RDL 3/2012, de 10 de febrero, de medidas urgentes para la reforma del mercado laboral, convalidado luego por la Ley 3/2012, de 6 d julio, de medidas urgentes para la reforma del mercado laboral. 